\title{
Diyabetik Ayak Yaraları Üzerine İmmunohistokimyasal Bir Çalışma; MMP-2 ve TNF- $\alpha$ Ekspresyonlarının İncelenmesi
}

An immunohistochemical study on diabetic foot wounds; examination of MMP-2 and TNF= a expressions

\author{
Murat Baloğlu1 (D), Ebru Gökalp Özkorkmaz \\ 1 Dr, Gazi Yaşargil Eğitim ve Araştırma Hastanesi, Fizik Tedavi ve Rehabilitasyon Kliniği, Diyarbakır, Türkiye \\ 2 Dr Ögr Üyesi, Dicle Üniversitesi Tıp Fakültesi Histoloji-Embriyoloji ABD, Diyarbakır, Türkiye
}

\section{Öz.}

Amaç: Diyabetik ayak, diyabetin önemli ve uzun süreli komplikasyonlarından biridir. Bilindiği üzere diyabetik bireylerde yara iyileşmesi yavaş olmaktadır ve bu duruma bakteriyel invazyonun eklenmesi sonucu uzun süreli inflamasyon eşliğinde iyileşmeyen diyabetik ayak yaraları ortaya çıkmaktadır. Söz konusu çalışmanın amacı, diyabetik ayak yara dokusunda proinflamatuvar sitokinlerden TNF-a ve kollajenin parçalanmasında rol oynayarak dokunun yeniden şekillenmesini sağlayan matriks metaloprotein MMP-2 ekspresyonunu immunohistokimyasal yöntemlerle tespit etmektir.

Materyal ve Metot: Bu çalışmaya 30 erkek ve 30 kadın olmak üzere, diyabetik ayak tanısı almış, ve ayaklarında açık yara bulunan 60 birey dahil olmuştur. Çalışmaya alınacak ayak, izotonik çözelti ile yıkandıktan sonra yaralar kesilip çıkarılış ve dokular \%10'luk formaldehit solüsyonunda tespit edilmiştir. Rutin histolojik takip sonrası kesitler parafine gömülmüş ve yarıince kesitleri alınarak histopatolojik incelemeleri yapılmışıı. İmmunohistokimyasal analiz için, doku örnekleri, MMP-2 ve TNFa primer antikorları ile boyanarak mikroskop altında incelenmiş̧ir.

Bulgular: Çalışmamızın sonuçlarına göre diyabetik ayak yara dokusunda, ligamenter dokunun içinde lökositter, lenfositler ve monositlerin yoğun olduğu izlenmiştir. Kollajen liflerde dejenerasyon ve kan damarlarında dilatasyon, konjesyon ve ödem görülmüştür. İnflamatuvar hücrelerde ve nekroze olan alanlarda TNF-a ekspresyonunda artış izlenmiştir. Damar çevresinde görülen yoğun inflamasyonunun arasında, dejenere kollajen lif ve fibroblast hücreleri ve ekstrasellüler matrikste MMP-2 ekspresyonu pozitif olarak gözlenmiştir.

Sonuç: Diyabetik ayak yarası tedavisinde MMP ekspresyonu yönünde düzenleme yapılarak, her geçen gün genişleyen diyabetik popülasyonda iyileşmeyen ayak yaralarına karşı bir yaklaşım geliştirilebilir düşüncesindeyiz.

Anahtar Kelimeler: Diyabetik ayak, MMP-2, TNF- a, Histopatoloji, Immunohistokimya

Abstract

Background: Diabetic foot is one of the major and long-term complications of diabetes. As known, wound healing is slow in diabetic individuals and as a result of inclusion of bacterial invasion to this condition, non-healing diabetic foot wounds occur with prolonged inflammation. The aim of this study was to determine the expressions of TNF-a, a proinflammatory cytokine and matrix metalloprotein MMP-2, involved in tissue remodeling via collagen degradation by immunohistochemical methods in diabetic foot wound tissues.

Methods: This study included 30 males and 30 females, a total of 60 patients diagnosed with diabetic foot having open wounds. After washing the foot with isotonic solution, the hole wounds were cut and tissues were fixed in $10 \%$ formaldehyde solution. After routine histological follow-up, the sections were embedded in paraffin and semi-thin sections were cut and histopathological examinations were performed. For immunohistochemical analysis, tissue samples were stained with MMP2 and TNF-a primary antibodies and examined under a microscope.

Results: In our study, leukocytes, lymphocytes and monocytes were observed in the diabetic foot wound tissue. Degeneration of collagen fibers and dilatation of blood vessels, congestion and edema were observed. TNF-a expression was increased in inflammatory cells and necrosis areas. MMP-2 expression was found to be positive in degenerated collagen fibers, fibroblasts and extracellular matrix among the intense inflammation around the vein.

Conclusion: Regarding the MMP expression in diabetic foot wound treatment, we think that an approach to the healing of non-healing foot wounds may be developed in the diabetic population.

Keywords: Diabetic foot, MMP-2, TNF- a, Histopathology, Immunohistochemistry

\section{Sorumlu Yazar I \\ Corresponding Author}

Dr. Ebru Gökalp Özkorkmaz

Dicle Üniversitesi Tıp Fakültesi Histoloji Embriyoloji ABD, Diyarbakır, Türkiye 21010

Tel: 041224880 01/4122

e-mail: ebrug76@gmail.com

Geliş tarihi / Received: 15/03/2019

Kabul tarihi / Accepted: 10/05/2019

DOI: 10.35440/hutfd.540551 


\section{Giriş}

Diyabetin alt ekstremitelerdeki komplikasyonları arasında ayak ülseri, enfeksiyon ve derin dokuların tahribatı, nörolojik anomaliler ve periferik vasküler yetersizlik yer almaktadır. Diyabetik ayak, mikrobiyal patojenlerin sebep olduğu enfeksiyonlar ve bunlara verilen inflamatuvar cevaba bağlı olarak doku hasarı ortaya çıkar $(1,2)$. Diyabetik hastalarda özelikle görülen yara iyileşmesinde gecikme, yaranın kronikleşmesi ilaveten yetersiz enfeksiyon kontrolü amputasyona kadar gidebilen durumlara neden olabilmektedir. Travmatik olmayan alt ekstremite ampütasyonlarının \% 85'i diyabetiklerde meydana gelmektedir (3). Tip 2 diyabette görülen hiperglisemi ve oksidatif stres dokularda inflamatuvar sitokinlerin fazlaca salgılanmasına ve glikasyon ürünlerinin meydana gelmesine ve kök hücrelerinin farklılaşma potansiyellerinin azalmasına neden olmaktadır (4). Ayrıca diyabette görülen insülin direncinin, inflamasyon gibi olaylar üzerine lokal ve sistemik etkileri vardır. Diyabete bağlı olarak gelişen vasküler yetersizlik sonucu, nötrofil hücrelerinin dokudaki göçünde azalma, doku canlılı̆ında kayıp ve yaraların geç iyileşmesi ortaya çıkmaktadır. Diyabete bağlı, uzun süreli TNF- $\alpha$ (Tümör Nekroz Faktörü) ekspresyonu yara iyileşmesi sürecini bozmaktadır (5). TNF- $\alpha$ nın, immün sistem hücreleri tarafindan lokal olarak eksprese edildiğinde terapötik etki gösterdiği fakat, disregüle edilerek ve dolaşıma verildiğinde, bir seri hastalıklara neden olduğu bilinmektedir. TNFa hücresel transformasyon, hücrenin canlılı̆ını sürdürmesi, proliferasyonu, invazyon, anjiyogenez, metastaz gibi pek çok olaya dahil olmaktadır (6). Pro-inflamatuvar sitokinler (örn. TNF- $\alpha$ ) ve matriks metalloproteinazlar (MMP) arasında sıkı bir ilişki vardır. TNF- $\alpha$ gibi tetikleyici sinyallerin yara iyileşmesi sürecine dahil olması sonucu MMP'ler de aktive olmaktadırlar (7). MMP'ler, proteolitik enzimlerdir ve morfogenez, yara iyileşmesi, hücre göçü ve anjiyogenez, kemik ve kıkırdak dokunun onarımı gibi olaylarda rol oynarlar. Hücre dışı proteinleri degradasyona uğratmak suretiyle hücre dışı matriksi yeniden şekillendirirler. Bu nedenle, anjiyogenez için önemli oldukları öne sürülmüştür $(8,9)$. MMP'lerin, büyüme faktörleri, sitokinler, hücre-hücre ve hücre dışı matriks adezyon molekülleri gibi çeşitli faktörler tarafından uyarıldığı bilinmektedir (10). MMP ler arasında en iyi bilinenlerinden biri MMP-2dir. MMP-2, hemen hemen tüm hücre tiplerinde bulunur ve diğer hücre dışı matriks proteinlerinin yanı sıra denatüre kollajen (jelatin) ve kollajen tip 4 'ü (bazal membranın bir bileşeni) degrade eder (11). Bu çalışmada, immünohistokimyasal yöntemler kullanılarak tip 2 diyabetli hastaların ayaklarındaki yaralardan alınan doku örneklerinde inflamasyon, anjiyogenik etkiler, hücre etkileşimlerini incelemek amaçlanmıştır.

\section{Materyal ve Metod \\ Deneysel Süreç}

Bu araştırmada Gazi Yaşargil Eğitim ve Araştırma Hastanesi, Fizik Tedavi ve Rehabilitasyon Kliniği'ne Mayıs 2017-Ekim 2018 arasında diyabetik ayak şikayeti ile gelen hastalardan, 30 erkek ve 30 kadın olmak üzere, diyabetik ayak tanısı almış, ve ayaklarında açık yara bulunan 60 birey dahil edildi ve hastalardan çalışma öncesi onam formları alındı. Hastalar sırtüstü yatar pozisyonda iken, ayakları izotonik salinle yıkandıktan sonra açık yaranın cerrahi debridmanı yapıldı ve eksize edilen dokular inceleme için tespit solüsyonu olarak $\% 10$ luk formaldehite alındı, dehidrasyon için artan etanol serilerinden geçirildi ve parafine gömüldü. Mikrotom (Leica, Almanya) ile yarıince kesitleri alınan dokular histopatolojik inceleme için Hematoksilen- Eosin ile boyandı ve mikroskop altında incelendi.

\section{Immunohistokimyasal incelemeler için dokuların hazırlanması}

Parafin bloklardan alınan kesitler distile suya alındı ve fosfat tamponu ile hazırlanmış salin (PBS) solüsyonunda $3 \times 5$ yıkandı. Antijen (Katalog no10010023, Thermo Fisher Scientific Fremont, USA) retrieval mikrodalgada $3 \mathrm{dk}$, $90^{\circ} \mathrm{C}$ de yapıldı. Kesitler proteoliz için sitrat tampon solüsyonu içinde $(\mathrm{pH} \mathrm{6})$, mikrodalgada ısıtma işlemine tabi tutuldular. Kesitler $3 \times 5$ kez PBS ile yıkandı ve hidrojen peroksit (Merck, ABD) (3ml \%30 Hydrogen peroxide $\left(\mathrm{H}_{2} \mathrm{O}_{2}\right)+27 \mathrm{ml}$ methanol) ile 20dk inkübe edildi. Kesitler yine $3 \times 5$ kez PBS ile yıkandı ve 8dk Ultra V Block (lot: PHL150128, Thermo Fisher, ABD) ile muamele edildi. Süzüldükten sonra, primer antikorlar MMP-2(Matrix Metalloprotein-2 monoclonal antibody 1:100, Cat\#PA1-16667, Thermo Fisher,ABD) ve TNF-a (Cat \# 14-7321-81 Thermo Fisher, ABD) direkt olarak kesitlere uygulandı. Kesitler bir gece $+4^{\circ} \mathrm{C}$ 'de bekletildi. Kesitler $3 \times 5$ dk PBS ile yıkandıktan sonra Biotin işaretli sekonder antikor (lot: PHL150128, Thermo Fischer, ABD) ile14 dk inkübe edildi. PBS ile yıkandıktan sonra $15 \mathrm{dk}$ Streptavidin Peroxidase (lot: PHL150128, Thermo Fischer, ABD) ile muamele edildi. Tekrar $3 \times 5$ kez PBS ile yıkanan kesitlere $10 \mathrm{dk}$ DAB (lot: HD36221, Thermo Fischer, ABD) uygulandı. Reaksiyon görülen lamlar PBS ile yıkandı. Zıt boyaması 45 dk Harris's Hematoksilen (Sigma, Hematoxylin Solution, Harris Modified, ABD) ile gerçekleştirildi, Lamlar Entellan (Sigma, ABD) ile kapatılı ve Zeiss Imager A2 (Almanya) ışık mikroskobu ile incelendi.

\section{Bulgular \\ Histopatoloji Bulguları}

Erkek ve kadın hastaların diyabetik ayaktaki lezyon dokusunun yapısal özellikleri ve hücresel bileşenleri histopatolojik olarak değerlendirildi. Erkek hastalardan alınan diyabetik ayak dokusu histopatolojik olarak incelendiğinde; ligamenter dokunun içinde artan lökositler, lenfositler, ve 
monositlerin yoğun olduğu izlenmiştir. Ayrıca, bu hücrelerin lezyonun her tarafına diffuz bir biçimde yayıldığı, özellikle küçük kan damarları etrafında lokalize olduğu görülmüştür. Kan damarlarında dilatasyon, konjesyon ve ödem görülmüştür. Bağ doku kollajen liflerinde yer yer dejeneratif değişikler izlenmiştir (Şekil 1a). Kadın hastaların diyabetik ayak dokusu histopatolojik olarak incelendiğinde; kan damarlarında dilatasyon, konjesyon, subendotelial tabakada dejeneratif değişiklikler, perivasküler alanda yoğun inflamasyon ve nekroze alanlar görüldü ve aynı alanda infiltrasyon izlendi. Kollojen fibrillerde organizasyon değişikliği ve hyalinizasyon soliter biçimde dağılmış inflamatuvar hücreler görüldü (Şekil 1b).

\section{Immunohistokimyasal çalışmalar}

İmmunohistokimya bulguları değerlendirildiğinde; erkek hastaların doku örneklerinde küçük gruplar şeklinde görülen inflamatuvar hücrelerde ve nekroze olan alanlarda TNF-a ekspresyonunda artış, bozulmuş kollojen liflerin arasında diffüz dağılmış lokositer hücrelerde TNF-a ekspresyonu pozitif olarak gözlendi (Şekil 2a). Kadın hastaların immunohistokimyasal incelemesinde ise kan damarları etrafındaki inflamatuvar hücrelerin yoğun olduğu ve nekroze alanlar içine yayılmış lökositer hücrelerde TNF- a ekspresyonlarının güçlü olduğu görülmüştür (Şekil 2b). Erkek hastalardan alınan başka bir kesitte ise damar çevresinde görülen yoğun inflamasyonunun arasında dejenere kollajen lif ve fibroblast hücreleri ve ekstrasellüler matrikste MMP-2 ekspresyonu pozitif olarak gözlendi (Şekil 2c). Kadın hastaların diyabetik ayak kesitlerinde ise artmış kollajen lif dejenerasyonu ve fibroblast hücre çekirdeklerinde piknosis ve apoptotik değişikler görülürken bu yapılarda MMP-2 ekspresyonunun pozitif olduğu tespit edildi (Şekil 2d).

\section{Tartışma}

Bilindiği gibi diyabette, hipergliseminin kontrol altına alınmaması, proinflamatuvar etmenler, perivasküler hastalıklar eşliğinde periferal nöropati, endotelyal disfonksiyon ve etkin olmayan immün cevap bileşkesinde immün hücrelerinin fonksiyonları bozulmakta ve nihayetinde yara iyileşmesi süreci zarar görmektedir (12). Diyabetik ayak ülserleri de çeşitli nedenlerden kaynaklanmaktadır; nöropati, ayakta meydana gelen travma ve deformite, diyabetik ayak yaralarının sebeplerindendir (13). İnflamasyon, immün sistem yetersizliği, periferal vasküler hastalıklar nedeni ile meydana gelen iskemi, ve enfeksiyon iyileşmeyen diyabetik ayak yaralarının altında yatan sebeplerdir (14).

Diyabetiklerde fibroblast ve endotelyal hücre proliferasyonu azalmakta, kollajen yapısı bozulmaktadır. Çalışmamızda, diyabetik ayak yarasında, ligamenter dokunun içinde lökositlerin arttığı, lenfositler ve monositlerin yoğun olduğu gözlenmiştir. Bağ doku kollajen liflerinde yer yer dejeneratif değişikler izlenmiştir.
Yaralanmadan hemen sonra insan yaralarında ve deneysel modellerde interlökin (IL) ve TNF- $\alpha$ gibi proinflamatuvar sitokinlerin arttığı belirlenmiştir. Bazı proinflamatuvar sitokinler ve kemokinler normal deri yarasının iyileşmesi için elzemdir (15). Tip 2 diyabetik bireylerde de insülin direncine bağlı olarak, serumda TNF- $\alpha$ düzeyinin arttığı bildirilmiştir (16). TNF-a, fibroblast ve endotel hücrelerinde apoptozu teşvik ederek granülasyon dokusunu azaltmaktadır. Yaraya TNF-a uygulanması, yara direncini de azaltmaktadır çünkü, kollajen Tip 1 ve 3 ekspresyonları azalmaktadır (17). TNF-a, fibroblast ve vasküler öncü hücreleri intoksike etmekte ve fibroblastların proliferasyon ve göçü ve matriks bileşenlerinin sentezi önlenmektedir (4). Çalışmamızda ayak yara dokusunda inflamatuvar hücrelerde ve nekroze olan alanlarda TNF-a ekspresyonunda artış, bozulmuş kollajen liflerin arasında diffüz dağılmış lokositer hücrelerde TNF-a ekspresyonu pozitif olarak gözlenmiştir.

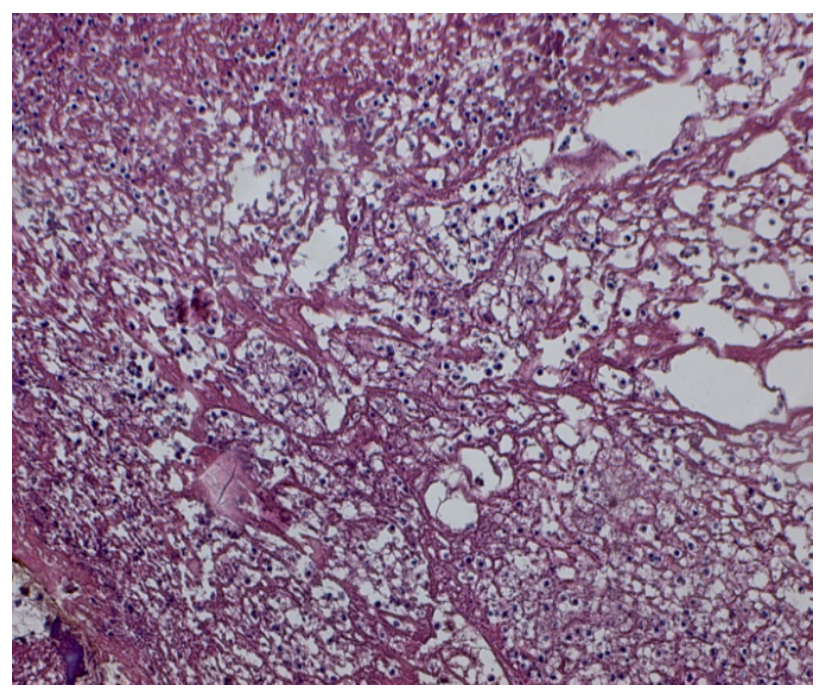

Şekil 1a. Erkek ve kadın hastalara ait diyabetik ayak dokuları, H-E boyama, Büyütme: X40

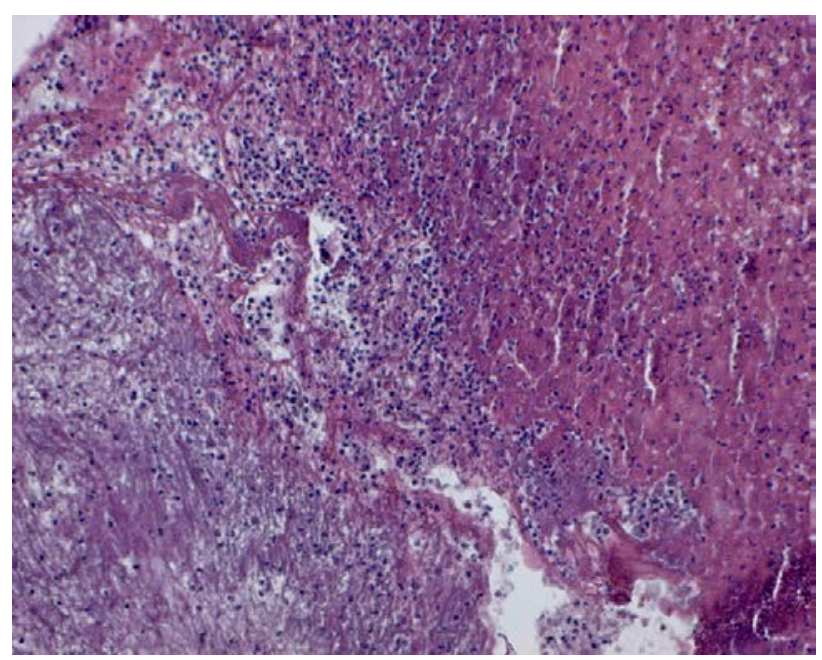

Şekil 1b. Erkek ve kadın hastalara ait diyabetik ayak dokuları, H-E boyama, Büyütme: X40 


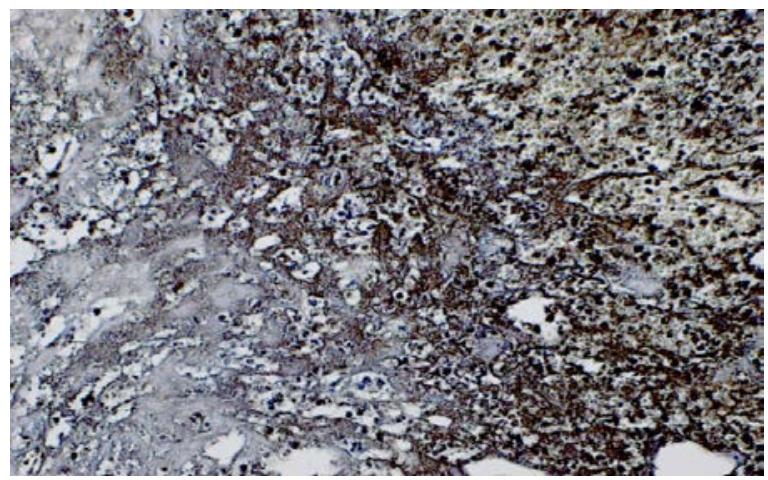

Şekil 2a. Erkek hastalara ait diyabetik ayak dokularında TNF-a boyaması, Büyütmex40

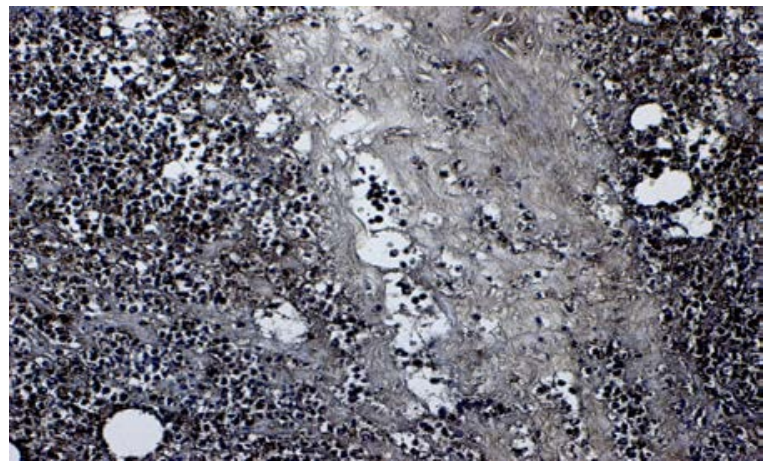

Şekil 2b. Kadın hastalara ait diyabetik ayak dokularında TNF-a boyaması, Büyütme x40

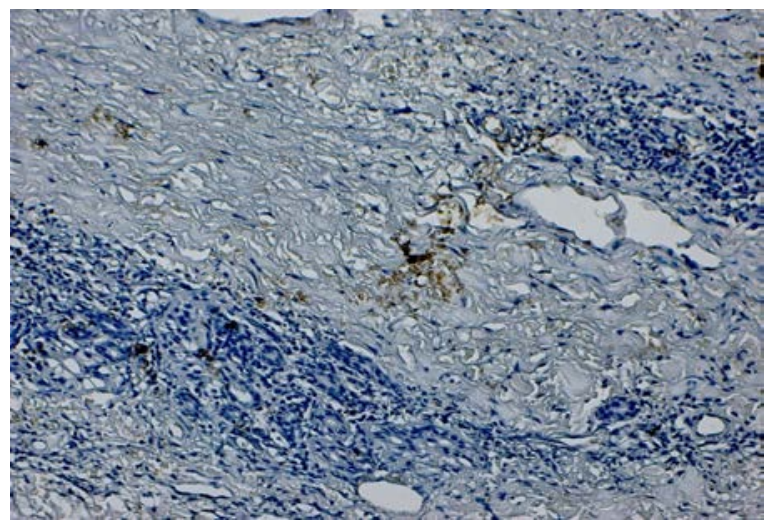

Şekil 2c. Erkek hastalara ait diyabetik ayak dokularında MMP-2 boyaması, Büyütme x40

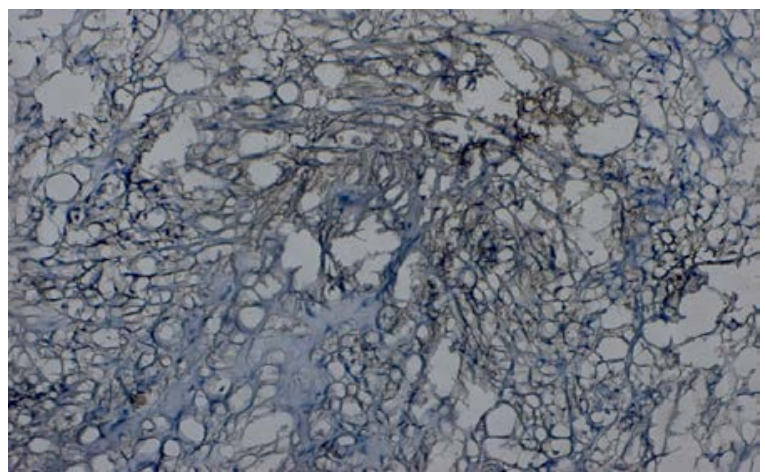

Şekil 2d. Kadın hastalara ait diyabetik ayak dokularında MMP-2 boyaması, Büyütme x40
In vivo ve in vitro çalışmalar MMP'lerin direkt veya indirekt olarak yara iyileşmesi ve neovaskülerizasyon sürecine dahil olduklarını göstermiştir. Dolayısıyla, MMPlerin doku homeostazının sağlanmasında rol oynadığı söylenebilir. Doku hasarının ardından, çeşitli MMPler uyarımakta ve mezenşimal, epitelyal ve immün hücreler tarafından eksprese edilmektedirler. MMPler, yara dokusunda MMP-2 ve -9 yoluyla, hücre dışı matrikse bağlı pro-anjiyogenik faktörlerin (TNF- a, VEGF gibi) salınmasını uyarırlar. MMP2'nin, fibroblast ve endotelyal hücreler tarafından üretildiği bilinmektedir (18). Çalışmamızda artmış yara dokusunda kollajen lif dejenerasyonu ve fibroblast hücre çekirdeklerinde piknosis ve apoptotik değişikler gözlenmiş ve MMP2 ekspresyonunun pozitif olduğu tespit edilmiştir.

Diyabetik ayak yaralarına karşı terapötik çalışmalar günümüzde devam etmektedir bu yaklaşımların amacı, yara bölgesindeki hiperinflamasyonu indirgemek ve/veya glukotoksisiteyi hafifletmek için bu olaylara neden olan efektör yolakları ortadan kaldırmaktır (4). Bu yöntemlerle, her geçen gün genişleyen diyabetik popülasyonda iyileşmeyen ve ampütasyona kadar ilerleyen diyabetik ayak yaralarının azalması hedeflenmektedir. Bu çalışmada ortaya koyulan sonuçlara göre, diyabetik hastalarda hiperglisemi ve oksidatif stres sonucu gelişen ekstraselüler matriks mekanizmasının bozulması ve inflamasyonun artması hastalığın seyrini olumsuz yönde etkilerken, matriks metaloprotein aktivitesinde tedavi yönünde düzenleme yapıldığında iyileşmenin daha hızlı gelişebileceği düşünülmüştür.

\section{Kaynaklar}

1. Rodrigues J, Mitta N. Diabetic Foot and Gangrene. In Tech Open 2011; 29: 1-25.

2. Williams DT, Hilton JR, Harding KG. Diagnosing foot infection in diabetes. Clin Infect Dis 2004; 39: 83-6.

3. Berlanga J, Valdéz C, Savigne W. Cellular and molecular insights into the wound healing mechanism in diabetes, Biotecnol Apl 2010; 27: 255-61.

4. Acosta JB, del Barco DG, Vera DC et al. The pro-inflammatory environment in recalcitrant diabetic foot wounds. Int Wound J 2008; 5(4): 530-9.

5. Xu F, Zhang C, Graves DT. Abnormal cell responses and role of TNF-a in impaired diabetic wound healing. BioMed Res Int 2013; 754802.

6. Aggarwal BB. Signalling pathways of the TNF superfamily: a double-edged sword, Nat Rev Immunol 2003; 3(9): 745-56.

7. Wetzler C, Kampfer H, Stallmeyer B, Pfeilschifter J, Frank S. Large and sustained induction of chemokines during impaired wound healing in the genetically diabetic mouse: prolonged persistence of neutrophils and macrophages during the late phase of repair, J Invest Dermatol 2000;115: 245-253.

8. Nagase $\mathrm{H}$, Woessner JF. Matrix metalloproteinases, J Biol Chem 1999; 274(31): 21491-4.

9. Overall CM, Lopez-Otin C. Strategies for MMP inhibition in cancer: innovations for the post-trial era, Nat Rev Cancer, 2002; 2: $657-72$.

10. Hu J, Van den Steen PE, Sang QX, Opdenakker G. Matrix metalloproteinase inhibitors as therapy for inflammatory and vascular diseases. Nat Rev Drug Discov 2007; 6(6):480-98. 
11. Sawicki G. Intracellular Regulation of Matrix Metalloproteinase-2 Activity: New Strategies in Treatment and Protection of Heart Subjected to Oxidative Stress. Scientifica 2013; ID 130451.

12. Tellechea A, Le Veves A, Carvalho E. Inflammatory and angiogenic abnormalities in diabetic wound healing: role of neuropeptides and therapeutic perspectives, Open Circ Vasc J 2010; 3: 43-55.

13. Leung PC. Diabetic foot ulcers, a comprehensive review. Surgeon 2007; 5(4): 219-31.

14. Sibbald RG, Woo KY. The biology of chronic foot ulcers in persons with diabetes, Diabetes Metab Res Rev.2008; 24(1): 25-30.

15. Barrientos S, Stojadinovic O, Golinko MS, Brem H, Tomic-Canic M. Growth factors and cytokines in wound healing, Wound Repair Regen 2008; 16(5): 585-601.

16. Borst SE. The role of TNF-alpha in insulin resistance. Endocrine 2004; 23(2-3): 177-82.

17. Rapala K, Laato $M$, Niinikoski J, et al. Tumor necrosis factor alpha inhibits wound healing in the rat. Eur Surg Res 1991;23: 261-8.

18. Löffek S, Schilling O, Franzke CW. Biological role of matrix metalloproteinases: A critical balance. Eur Respir J 2011; 38: 191-208. 